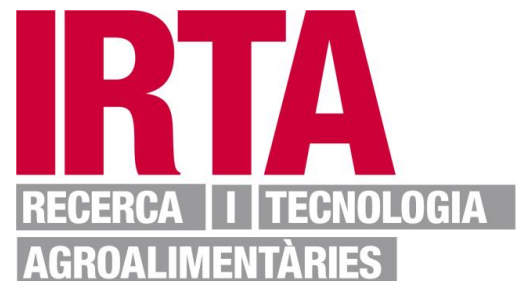

This document is a postprint version of an article published in International Journal of Food Microbiology (c) Elsevier after peer review. To access the final edited and published work see https://doi.org/10.1016/j.ijfoodmicro.2020.108810

Document downloaded from:

IRTAPubpro

Open digital archive 


\section{Evaluation of a sanitizing washing step with different chemical disinfectants for} the strawberry processing industry

3

4 Ortiz-Solà1 ${ }^{1}$ J., Abadias²*, M., Colás-Medà², P., Sánchez ${ }^{3}$, G., Bobo², G., Viñas ${ }^{1 *}$, I.

5

61 Universitat de Lleida. Departamento de Ciencia y Tecnología de Alimentos. XaRTA-

7 Postharvest. Centro Agrotecnio. Rovira Roure 191, 25198 Lleida.

82 Institut de Recerca i Tecnologia Agroalimentàries (IRTA). XaRTA-Postharvest. Edifici

9 Fruitcentre, Parc Científic i Tecnològic Agroalimentari de Lleida, Parc de Gardeny, 25003 Lleida.

103 Departamento de Tecnologías de Conservación y Seguridad Alimentaria., IATA-CSIC, Avda.

11 Agustin Escardino 7, 46980 Paterna, Valencia, Spain

12

13 * Corresponding autor: I. Viñas (ivinas@tecal.udl.cat) / M. Abadias (isabel.abadias@irta.cat) 


\section{Highlights}

16

- Chemical sanitizers selected may be a feasible alternative to chlorine (100 ppm) sanitization.

- Inoculated L. monocytogenes and S. enterica were reduced at least 2-log units.

- MNV-1 infectivity was decreased by $\geq 1.7 \log$ TCID $_{50}$.

- Physio-chemical parameters studied did not overcome major changes.

22

- Peracetic acid (PA) was effective for washing water and fruit disinfection. 


\section{Abstract}

Strawberries are often consumed fresh or only receive minimal processing, inducing a significant health risk to the consumer if contamination occurs anywhere from farm to fork. Outbreaks of foodborne illness associated with strawberries often involve a broad range of microbiological agents, from viruses (human norovirus) to bacteria (Salmonella spp. and Listeria monocytogenes). The addition of sanitizers to water washes is one of the most commonly studied strategies to remove or inactivate pathogens on berries as well as avoid cross contamination due to reuse of process wash water. The risk posed with the safety issues of by-products from chlorine disinfection in the fruit industry has led to a search for alternative sanitizers. We evaluated the applicability of different chemical sanitizers (peracetic acid (PA), hydrogen peroxide $\left(\mathrm{H}_{2} \mathrm{O}_{2}\right)$, citric acid (CA), lactic acid (LA) and acetic acid (AA)) for the inactivation of S. enterica, L. monocytogenes and murine norovirus (MNV-1) on strawberries. A control treatment with chlorine $(\mathrm{NaClO})(100 \mathrm{ppm})$ was included. For each sanitizer, different doses (40, 80 and 120 ppm for PA and 1, 2.5 and $5 \%$ for $\mathrm{H}_{2} \mathrm{O}_{2}, \mathrm{LA}_{\text {, }}$ AA and CA) and time (2 and $5 \mathrm{~min}$ ) were studied in order to optimize the decontamination washing step. The best concentrations were 80 ppm for PA, $5 \%$ for $\mathrm{H}_{2} \mathrm{O}_{2}$ and $2.5 \%$ for organic acids (LA, AA and CA) after 2 min treatment. Results indicate that the sanitizers selected may be a feasible alternative to chlorine (100 ppm) for removing selected pathogenic microorganisms $(P>0.05)$, with reductions about $\geq 2 \log$ for bacterial strains and $\geq 1.7 \log$ for MNV-1. As the washing water may also increase the microbial counts by cross-contamination, we observed that no pathogenic bacteria were found in wash water after $5 \% \mathrm{H}_{2} \mathrm{O}_{2}$ and 80 ppm PA after 2 min treatment. On the other hand, we also reported reductions about total aerobic mesophyll (TAM) $(0.0-1.4 \log$ CFU/g) and moulds and yeasts (M\&Y) (0.3 - $1.8 \log$ CFU/g) with all alternative sanitizers tested. Strawberries treated did not shown significant differences about physiochemical parameters compared to the untreated samples (initial). For this study, the optimal sanitizer selected was PA, due to the low concentration and cost needed and its microbiocidal effect in wash water and fruit. Notwithstanding the results obtained, the effect of PA in combination with other non-thermal technologies such as water-assisted ultraviolet (UV-C) light should be studied in future research to improve the disinfection of strawberries. 


\section{Introduction}

Strawberries are one of the most important fruits in the Mediterranean diet. They are highly appreciated for their unique fragrance, nutritional value and antioxidant activity due to their vitamin C and polyphenol contents with nutraceutical properties (Mezzetti et al., 2014). Fresh strawberries are generally cultivated, hand-picked, packaged and commercialized in the fresh market, but are not subjected to any step that can eliminate postharvest pathogens. However, they are subjected to a washing process before processing (Janowicz et al., 2007; Velickova et al., 2018).

Foodborne illness outbreaks have been linked with the consumption of fresh or frozen strawberries that were contaminated with pathogenic viruses, parasites, or bacteria. The majority of outbreaks have been caused by enteric viruses, and many of the virus-associated outbreaks have been associated to frozen strawberries (Palumbo et al. 2013). In fact, Bozkurt et al. (2020) documented that human norovirus in soft red fruits was the most common and implicated pathogen in 46 foodborne outbreaks globally with over 15.000 cases during 1983-2018. Against this background, the EFSA (European Food Safety Authority, 2014) emitted a scientific opinion on the risk posed by human norovirus and Salmonella spp. in berries. Even though no bacterial pathogenic microorganisms have usually been found on field and sold retail strawberries (Delbeke et al., 2015; Ortiz-Solà et al., 2019a), Salmonella spp. and Listeria monocytogenes were able to survive on the fruit surface at different stored temperatures (Ortiz-Solà et al., 2019b; Sreedharan et al., 2015), and L. monocytogenes could grow in the conditions in which strawberries are stored (Siro et al., 2006). For this reason, EFSA Panel on Biological Hazards concluded that improper fruit handling practices and the use of contaminated washing water should be considered as sources of contamination, and it recommended that a decontamination step treatment should be integrated into the strawberry production chain in order to avoid possible foodborne outbreaks related to this fruit.

The addition of sanitizers to water wash is one of the most upsurge studied strategies to remove or inactivate pathogens on fresh and pre-cut fruits (Lafarga et al., 2019; Ramos et al., 2013). As 
the washing water may also increase the bacterial counts by cross-contamination, it is important that the washing step not only removes bacteria but also maintains water quality (Pablos et al., 2018). For example, norovirus or norovirus RNA could persist in some type of waters for 60 to 728 days and in fruits and vegetables for longer than product's shelf life (Cook et al., 2016).

Chlorine is the first choice as a disinfectant due to its low price, simplicity of use and effectiveness against vegetative bacteria (Ölmez and Kretzschmar 2009). However, its action is highly pHdependent and it reacts with organic matter, producing undesirable by-products such as trihalomethanes. Due to this, it has been banned as a wash for produce in some European countries, including Germany, the Netherlands, Switzerland, Denmark and Belgium (Artes et al., 2009; Rico et al., 2007). These drawbacks have encouraged the search for alternatives to chlorine in wash water (Meireles et al., 2016). Organic acids, which are considered 'Generally Recognized as Safe' (GRAS) by FDA, have been described as strong antimicrobial agents due to environment $\mathrm{pH}$ reduction, disturbance of membrane transport and/or permeability, anion accumulation, or a reduction in internal cellular pH (Beuchat, 1995; Harris et al., 2003; Miller et al., 2009). These sanitizers are stable compounds that may persist on produce surfaces for a long period, avoiding bacterial attachment (De Villiers et al., 1997). Citric (CA) and acetic acids (AA) are commonly used in fruit and vegetable washing and added in fruit juices, such as vinegar and lemon juice (Lynch et al., 2019). Lactic acid (LA) is also frequently used in the food industry to reduce microbial populations and previous studies with produce models such as chicory, tomatoes, and lettuce have demonstrated that lactic acid is an effective antimicrobial treatment (del Carmen Velazquez et al., 2009; Trevisani et al., 2017). However, no studies have demonstrated yet the antimicrobial effectiveness of LA on berries. Indeed, there are numerous studies in reference to the effectiveness of all these organic acids against pathogenic bacteria and the microbiota of some fruits and vegetables. Though, there is much less information about its effectiveness against viruses (Lafarga et al., 2019).

Hydrogen peroxide $\left(\mathrm{H}_{2} \mathrm{O}_{2}\right)$ and peracetic acid (PA) have also been evaluated as potential substitutes for sodium hypochlorite $(\mathrm{NaClO})$, which bacteriostatic and bactericidal activity caused 
by a strong oxidizing power of C-C bonds and the maintaining of water washing quality (Wessels

107 and Ingmer, 2013). Their mode of action would imply a poor chance for the development of 108 resistance in microorganisms, as borne out by the absence of such reports in the literature 109 (Nicolau-Lapena et al., 2019).

110 Alternative disinfection methods to chlorine must be found in order to provide consumers with 111 safe fresh-cut, frozen and processed strawberries. Hence, the objective of this study was to 112 establish the optimal concentration/time procedure of different sanitizers: organic acids (LA, AA 113 and $\mathrm{CA}$ ), $\mathrm{H}_{2} \mathrm{O}_{2}$ and PA as sanitizers in strawberry washing processes on artificially inoculated 114 strawberries with Salmonella, L. monocytogenes and murine norovirus, a norovirus surrogate. 115 The effects of these products on native microbiota and their effects in the physico-chemical 116 quality of strawberries were also determined. 


\section{Materials and Methods}

Strawberries (Fragaria $\times$ ananassa), were purchased from local distributors in Lleida (Catalonia,

Spain) the day before the experiment and stored at $4 \pm 1{ }^{\circ} \mathrm{C}$ for $24 \pm 2 \mathrm{~h}$.

For the disinfection, acetic acid 99-100 \% w/v (AA) was purchased from Normapur VWR (Llinars del Vallés, Spain). Peracetic acid $15 \%$ w/v (PA), sodium hypochlorite $10 \%$ w/v (NaClO), hydrogen peroxide $33 \% \mathrm{w} / \mathrm{v}\left(\mathrm{H}_{2} \mathrm{O}_{2}\right)$, pure anhydrous citric acid (CA) and pure lactic acid (LA) were procured by Panreac AppliChem (Barcelona, Spain). Triptone soy broth (TSB), triptone soy agar (TSA), plate count agar (PCA), dichloran rose bengale chloramphenicol agar (DRBC), PALCAM base agar, yeast extract (YE), Xylose-Lysine-Desoxycholate Agar (XLD) and peptone were purchased from Biokar Diagnostics (Allonne, France).

\subsection{Microorganism preparation}

\subsubsection{Pathogenic bacteria}

The bacterial strains used in this work included the serovars of Salmonella enterica subsp. enterica: Agona (ATCC BAA-707), Michigan (ATCC BAA-709), Montevideo (ATCC BAA710), Gaminara (ATCC BAA-711) and Enteritidis (CECT-4300) in addition to the L. monocytogenes serovar 1a (CECT 4031), serovar 3a (CECT 933), serovar 4d (CECT 940), serovar 4b (CECT 4032) and serovar 1/2a, which was previously isolated in our laboratory from a fresh-cut lettuce sample (Abadias et al., 2008). For each strain of selected bacteria, a single S. enterica colony from a streak in TSA medium $\left(20-24 \mathrm{~h}, 37 \pm 1^{\circ} \mathrm{C}\right)$ was inoculated in $5 \mathrm{~mL}$ of TSB for $20-24 \mathrm{~h}$ at $37 \pm 1{ }^{\circ} \mathrm{C}$. L. monocytogenes strains obtained from a streak in tryptone soy agar plus $6 \mathrm{~g} / \mathrm{L}$ yeast extract (TSAYE) were grown individually in TSB supplemented with $6 \mathrm{~g} / \mathrm{L}$ of yeast extract, $2.5 \mathrm{~g} / \mathrm{L}$ glucose and $2.5 \mathrm{~g} / \mathrm{L} \mathrm{K}_{2} \mathrm{HPO}_{4}$ (TSBYE) for $20-24 \mathrm{~h}$ at $37 \pm 1{ }^{\circ} \mathrm{C}$. Bacterial cells were harvested by centrifugation at $9800 \times \mathrm{g}$ for $10 \mathrm{~min}$ at $10{ }^{\circ} \mathrm{C}$ (Sorvall Legend XTR Centrifuge, Thermo Fischer, US) and then resuspended in sterile saline solution (SS; $0.85 \% \mathrm{w} / \mathrm{v}$ $\mathrm{NaCl}$ ). Equal volumes of the five $S$. enterica concentrated suspensions were mixed to produce a 
single suspension, and equal volumes of the five L. monocytogenes concentrated suspensions were mixed to provide the 5-strain concentred cocktail. Afterwards, a volume of the concentrated bacterial suspension was added to saline peptone (SP; $8.5 \mathrm{~g} / \mathrm{L}$ and $1 \mathrm{~g} / \mathrm{L}$ peptone) and mixed to obtain approximately $10^{8}$ colony-forming units $(\mathrm{CFU}) / \mathrm{mL}$. The inoculum concentration was checked by plating appropriate dilutions on Palcam agar for L. monocytogenes (Palcam Agar Base with selective supplement, Biokar Diagnostics) or on XLD for S. enterica. Plates were incubated at $37 \pm 1{ }^{\circ} \mathrm{C}$ for $24 \pm 2 \mathrm{~h}$ (S. enterica) or $48 \pm 2 \mathrm{~h}$ (L. monocytogenes).

\subsubsection{Virus and cell culture}

Murine norovirus 1 (MNV-1), a surrogate of human norovirus, and murine macrophage cell line RAW 264.7 were kindly provided by Prof. H. W. Virgin (Washington University School of Medicine, US). MNV-1 stocks were propagated and quantified in the murine macrophage cell line RAW 264.7. Semi-purified MNV-1 virus was harvested at 2 days after infection by three freeze-thaw cycles of infected cells followed by centrifugation at $660 \times g$ for $30 \mathrm{~min}$ to remove cell debris (Sánchez et al., 2011). Infectious MNV-1 virus was enumerated by determining the 50 $\%$ tissue culture infectious dose $\left(\mathrm{TCID}_{50}\right)$. Stocks of MNV-1 (1 mL) were frozen until use (-80 $\left.{ }^{\circ} \mathrm{C}\right)$.

RAW 264.7 cells were cultured in Dulbecco's modified Eagle medium (DMEM; Hyclone, Pittsburgh, PA) supplemented with $10 \%$ fetal bovine serum (FBS; Hyclone) previously inactivated for $30 \mathrm{~min}$ at $56{ }^{\circ} \mathrm{C}$ in a water bath, $2 \mathrm{mM}$ glutamine, $10 \mathrm{mM} \mathrm{N}$-2hydroxyethylpiperazine-N0-2-ethanesulfonic acid, $2 \mathrm{mM}$ Glutamine, and $1 \%$ PenicillinStreptomycin (all from Biowest, US). The cell line was maintained at $37 \pm 1{ }^{\circ} \mathrm{C}$ in a $5 \% \mathrm{CO}_{2}$ humidified incubator (NU-4750, NuAire, US) in T175 flasks (Nunc, Thermo Fisher, US).

\subsection{Microorganism inoculation on strawberries}

The day before the experiment, strawberries were inoculated with $50 \mu \mathrm{L}$ of $S$. enterica and L. monocytogenes suspensions at $10^{8} \mathrm{CFU} / \mathrm{mL}$. Inoculated strawberries were stored at $4 \pm 1{ }^{\circ} \mathrm{C}$ overnight until the assay to facilitate bacterial establishment on fruits. In case of MNV-1, frozen 
stocks were defrosted $\left(1 \mathrm{~h}\right.$ at room temperature $\left.20-22{ }^{\circ} \mathrm{C}\right)$ and ten-fold diluted $\left(10^{7}\right.$ tissue culture infective dose $\mathrm{TCID}_{50} / \mathrm{mL}$ ) with Phosphate-Buffered Saline (PBS; ThermoFisher, US) before inoculation. Then, $50 \mu \mathrm{L}$ of MNV-1 were inoculated by pipetting small droplets on the surface of each strawberry and allowing them to dry for approximately $1-2 \mathrm{~h}$ in a biosafety laminar air cabinet (class II - type A, Telstar, Terrassa, Spain) at room temperature. Prior to the experiments, the initial concentration of S. enterica, L. monocytogenes and MNV-1 was checked as explained below.

\subsection{Experimental design}

Three types of experiments were carried out as indicated below. For all experiments, strawberries were removed from storage at $4{ }^{\circ} \mathrm{C}$ before the disinfection washing step.

\subsubsection{Evaluation of different chemical sanitizers on the population of bacterial} strains.

The first set of experiments consisted in determining the effect of different sanitizers' dose and exposition time on the survival of $L$. monocytogenes and S. enterica on strawberries. Products and doses tested were $1,2.5$ and $5 \%$ for $\mathrm{H}_{2} \mathrm{O}_{2}$, CA, LA and AA, and 40, 80 and 120 ppm for PA. A control treatment, $100 \mathrm{ppm}$ of $\mathrm{NaClO}$ adjusted to $\mathrm{pH}(6.5)$ using citric acid $2 \mathrm{M}$, was included. Each treatment was tested for 2 and 5 min. One single sanitizer at different concentrations and times was evaluated each day, using different strawberry batches. For washing, strawberries were immersed into $2 \mathrm{~L}$ beaker containing $1 \mathrm{~L}$ of distilled water $\left(8-12^{\circ} \mathrm{C}\right)$ and the sanitizer at the tested dose. The washing step was performed with constant agitation at $150 \mathrm{rpm}$ on an orbital shaker (Heidolph unimax 1010). After $100 \mathrm{ppm} \mathrm{NaClO}$ treatment, strawberries were rinsed in $1 \mathrm{~L}$ of cold tap water $\left(4^{\circ} \mathrm{C}\right)$ for $2 \mathrm{~min}$. Fruits were left to dry at room temperature. Free chlorine concentration was checked with an ion specific meter (model HI 95734-11, Hanna Instruments, Spain) and PA concentration was determined by iodometric titration with potassium permanganate and sodium hydroxide $(\mathrm{NaOH}) 2 \mathrm{M}$ (Panreac AppliChem, Barcelona, Spain). 
Furthermore, $\mathrm{pH}$ and ORP (Oxidation Reduction Potential) values were measured using $\mathrm{pH}$ meter (Crison GLP-22, Barcelona, Spain).

In the second set of experiments, optimum concentration and time selected for each sanitizer were tested all together in the same trial (using the same batch of strawberries and inoculum), in order to minimize the experimental variability arising from the heterogeneity of these variables. The procedures were the same that we commented above. Experiments were repeated twice.

To determine S. enterica and L. monocytogenes population, one artificially inoculated strawberry before and after disinfection was weighted, placed in a sterile filter bag $\left(80 \mathrm{~mL}\right.$ BagPage ${ }^{\circledR}$, Interscience BagSystem, Saint Nom, France) and diluted with buffered peptone water (BPW; Biokar Diagnostics) 1:4 (w:v). The content of the bag was mashed in a paddle blender (MiniMix, Interscience, France) for 2 min at 9 strokes/s. Aliquots of the mixture were serially diluted in saline peptone (SP; $0.85 \% \mathrm{w} / \mathrm{v} \mathrm{NaCl} ; 0.1 \% \mathrm{w} / \mathrm{v}$ Peptone), and plated in duplicate on XLD for enumerating S. enterica or on Palcam agar for L. monocytogenes. The agar plates were incubated at $37 \pm 1{ }^{\circ} \mathrm{C}$ for $24 \pm 2 \mathrm{~h}$ (S. enterica) or $48 \pm 2 \mathrm{~h}$ (L. monocytogenes). Three replications (three strawberries per treatment) were made at each sampling point. The data was transformed to log CFU/g strawberry. The limit of detection was $1.30 \log$ CFU/g strawberry. When no colonies were counted and detection was positive, an arbitrary number of half detection limit was estimated (1 $\log \mathrm{CFU} / \mathrm{g})$. Moreover, after each washing treatment, the population of $S$. enterica and L. monocytogenes were determined in the wash water, by adding $1 \mathrm{~mL}$ of wash water to neutralizing Dey-Engley medium (Fluka, Madrid, Spain) and were incubated at $37 \pm 1{ }^{\circ} \mathrm{C}$ for 24 \pm 2 and $48 \pm 2 \mathrm{~h}$. Other $100 \mu \mathrm{L}$ of wash water was plated in duplicate as described before. Results were expressed as $\log \mathrm{CFU} / \mathrm{mL}$, and the detection limit was $0.70 \log \mathrm{CFU} / \mathrm{mL}$. When quantification was below the detection limit, S. enterica and L. monocytogenes presence were confirmed by Dey-Engley change in colour followed by streaking onto XLD or Palcam.

2.4.2. Assessment of the sanitization washing step with the different optimal sanitizers on MNV-1 infectivity 
The optimal dose and exposition time for each sanitizer was selected from previous experiments (section 2.4.1). Treatments and procedures were performed as mentioned previously. For MNV1 extraction, one fruit after disinfection per treatment was placed in a small sterile filter bag ( 80 mL BagPage ${ }^{\circledR}$, Interscience, France) with $10 \mathrm{~mL}$ of Tris-Glycine Beef Extract buffer (TGBE; Biokar Diagnostics) in triplicate. The content was mixed with a homogenizer (MiniMix, Interscience, France) for $2 \mathrm{~min}$ at normal speed (7 strokes/s). The homogenate obtained were placed in $15 \mathrm{~mL}$ sterile tubes and centrifuged at $3000 \times \mathrm{g}$ for $10 \mathrm{~min}$ at $4{ }^{\circ} \mathrm{C}$. Supernatant was positioned in $2 \mathrm{~mL}$ Eppendorf and stored at $-80{ }^{\circ} \mathrm{C}$ until analysis.

Enumeration of MNV-1 on cell monolayers was done by the Spearman-Karber method as indicated above. Briefly, the day before determination, confluent RAW 264.7 cells grown in T175 flasks with DMEM $10 \%$ were transferred to $96-$ well microtiter plates with Hydrocell ${ }^{\mathrm{TM}}$ surface (ThermoFisher, US). Cell lines were stained with trypan blue (Biowest, US) and observed under the optical inverted microscope. The concentration needed per plate $\left(1.3 \times 10^{5}\right.$ cell $\left./ \mathrm{mL}\right)$ was determined with a Bürker chamber $\left(1 \mathrm{~mm}^{2}\right.$ surface $\times 0.1 \mathrm{~mm}$ depth $)$. Plates were incubated at 37 $\pm 1{ }^{\circ} \mathrm{C}$ in a $5 \% \mathrm{CO}_{2}$ for $24 \mathrm{~h}$. Subsequently, DMEM $10 \%$ was removed out the 96-well plates and $20 \mu \mathrm{L} /$ well of ten-fold dilutions of treated virus extract (sample) in PBS were inoculated into 8 wells/plate of confluent RAW 264.7 monolayers. Then, 96-well plates were incubated at same conditions commented above. After $1 \mathrm{~h}$ incubation, $150 \mu \mathrm{L} /$ well of DMEM supplemented with 2 $\%$ FBS were added and incubated again at $37{ }^{\circ} \mathrm{C}$ in a $\mathrm{CO}_{2}$ incubator for $2-3$ days. Cell monolayers were observed for cytotoxicity effects by visual inspection under the optical inverse microscope. Positive sample for MNV-1 was used as reference material in 4 wells/plate. Negative control was PBS, containing $2 \mathrm{M} \mathrm{NaNO3,} 1 \%$ beef extract, and $0.1 \%$ Triton X-100 (pH 7.2) spread in 4 242 wells/plate.

243 Number of infectious viruses was enumerated by determining the $50 \%$ tissue culture infectious 244 dose $\left(\mathrm{TCID}_{50}\right)$ with eight wells per dilution and $20 \mu \mathrm{L}$ of inoculum per well using the SpearmanKarber method (Pinto et al., 1994). The number of wells that had cytopathic effect after 48-72 h 
247 formula:

$$
M=x k+d[0.5-(1 / n)(r)]
$$

249 Where $x k$ was the dose of the highest dilution; $r$ was the sum of the number of "-" responses; $d$ 250 was the spacing between dilutions; and $n$ was the wells per dilution.

251 The reduction of MNV-1 on strawberries was calculated as $\log \left(\mathrm{N}_{\mathrm{x}} / \mathrm{N}_{0}\right)$, where $\mathrm{N}_{\mathrm{x}}$ is the infectious virus titer after each treatment and $\mathrm{N}_{0}$ is the initial virus infect titer (Falcó et al., 2018).

\subsubsection{Effect of different sanitizers on the microbiological quality of non-inoculated} strawberries

In experiments with epiphytic microbiota, the optimal dose and exposition time selected for each disinfectant was performed as discussed earlier in this report. This experiment was done once, with 3 determinations (repetitions). Three strawberries per treatment were weighed, placed in a sterile filter bag and diluted and homogenized as explained above. A 10-fold serial dilutions were made in SP and plated in duplicate on PCA for total aerobic mesophilic counts (TAM) and in DRBC for molds and yeasts (M\&Y). Plates were incubated at $30 \pm 1{ }^{\circ} \mathrm{C}$ for 3 days for TAM and at $25 \pm 1{ }^{\circ} \mathrm{C}$ for $3-5$ days for M\&Y. Results were expressed as $\log \mathrm{CFU} / \mathrm{g}$ and the detection limit was $1.70 \log \mathrm{CFU} / \mathrm{g}$. Moreover, after each washing treatment, the population of TAM and M\&Y was determined in the wash water. One milliliter of water was added to neutralizing Dey-Engley medium and plated as described before. Results were expressed as log CFU/mL, and the detection limit was $0.70 \log \mathrm{CFU} / \mathrm{mL}$. When quantification was below the detection limit, its presence was confirmed by Dey-Engley variation in colour and followed by streaking onto PCA or DRBC.

\subsubsection{Physicochemical Quality Analysis}

Physicochemical quality analyses were performed the same day of the experiments in noninoculated strawberries, before (initial) and immediately after treatments. This experiment was done once, with 6 determinations (repetitions). 
271 For $\mathrm{pH}$, titratable acidity (TA) and total soluble solids (TSS) determination, strawberries were

272 crushed in a paddle blender (MiniMix, Interscience, France). For each replication ( $\mathrm{n}=6$ fruits per

273 treatment), $25 \mathrm{~mL}$ of strawberry juice were needed, and analysed twice. $\mathrm{pH}$ was determined using

274 an electrode in a pHmeter (Crison GLP-21, Barcelona, Spain) equipped with a pH probe (ref. 52-

27503 , Crison). TA was measured by diluting $10 \mathrm{~mL}$ of strawberry juice with $10 \mathrm{~mL}$ of distilled water

276 and titrated with $0.1 \mathrm{M} \mathrm{NaOH}$. Results were expressed as g of citric acid per L. TSS was measured

277 at $20{ }^{\circ} \mathrm{C}$ with a refractometer (Atago Co. Ltd., Tokyo, Japan), and the results expressed as ${ }^{\circ}$ Brix.

278 Regarding to the colour, 6 strawberries per treatment was measured on 3 points of each strawberry

279 by using a CR-200 Minolta Chroma Meter (Minolta, INC., Tokyo, Japan). Colour was expressed

280 as CIE L*, $\mathrm{a}^{*}$, and $\mathrm{b}^{*}$ coordinates, using the D65 illuminant and a $10^{\circ}$ angle.

281 Changes in texture (firmness) was measured by the maximum penetration force using the TA. XT

282 Plus Connect texture analyser (Stable Micro systems Ltd., Surrey, England). The firmness test

283 was performed using the cylindrical probe of $4 \mathrm{~mm}$. Tests were run at $5 \mathrm{~mm} / \mathrm{s}$ speed and using a

284 trigger force of $0.1 \mathrm{~N}$, permitting the probe to enter $8.0 \mathrm{~mm}$ deep into the matrix tissue.

\subsection{Statistical Analysis}

286

All data were checked for significant differences by applying variance analysis (ANOVA) using the JMP14.0 (SAS Institute Inc., Cary, USA) statistical package. They were subjected to mean separation by least significant differences by Tukey's Honest Significant Difference (HSD) test $(P<0.05)$. 


\section{Results and Discussion}

\subsection{Evaluation of chemical sanitizers on the population of $S$. enterica and $L$. monocytogenes}

\subsubsection{Optimum concentration and time exposition}

Concentrations of sanitizers, $\mathrm{pH}$ and ORP values are detailed in Table 1. In the PA and organic acids (LA, AA and CA) washing solutions, $\mathrm{pH}$ and ORP values were lower than those observed in $\mathrm{NaClO}$ treatment, which ranged from 6.6 to 6.8 and $873-898 \mathrm{mV}$, respectively. The $\mathrm{H}_{2} \mathrm{O}_{2}$ treatments had the highest $\mathrm{pH}$ values and the lower ORP units, due to the basic nature of the product.

Regarding the washing time, 2 or 5 min, no significant differences $(P<0.05)$ were observed between washing 2 or 5 min with all sanitizers tested (data not shown). Therefore, 2 min treatment was selected for subsequent experiments. Previous publications have used $2 \mathrm{~min}$ as optimal time for their experiments and achieved $>3.0 \mathrm{log}$ CFU/g reduction, showing efficacy for significant removal of bacterial strains (includes Salmonella spp. and L. monocytogenes), as well as three tested virus strains (murine norovirus (MNV-1), hepatitis A virus (HAV) and bacteriophage MS2) on strawberries (Huang et al., 2015; Nicolau-Lapena et al., 2019; Wang and Ryser, 2014).

S. enterica and L. monocytogenes average reductions obtained for each treatment after 2 min are shown in Table 2. Peracetic acid (PA) treatments achieved higher significant average reductions of pathogenic bacteria in comparison to the $\mathrm{NaClO}(100 \mathrm{ppm})$ control treatment $(P<0.05) . L$. monocytogenes and S. enterica were below detection limit after washing in all doses tested, with reductions ca. 3.8 and $4.1 \log$ units, respectively. There were not significant differences $(P>0.05)$ among PA doses studied. In fact, reductions of about $4 \log$ units observed in study conducted by Singh et al. (2018) were in accordance with the present investigation, which also found no statistical differences between different concentrations of 45 or 85 ppm PA washings for 5 min on lettuce, cantaloupe, tomato, lemon, and blueberry. 
315 Results of microorganisms in the water washing are also shown in Table 2. In the case of PA, the 316 intermediate concentration of $80 \mathrm{ppm}$ was chosen, since this concentration preserved the wash water quality, avoiding the possibly subsequent cross-contamination of the fruit. Moreover, the $80 \mathrm{ppm}$ dose is permitted for the washing of fruits and vegetables in the United States (FDA CFR173.315).

On the other hand, reductions of $\geq 4.9 \log \mathrm{CFU} / \mathrm{g}$ were reported for L. monocytogenes and S. enterica with $5 \%$ of hydrogen peroxide $\left(\mathrm{H}_{2} \mathrm{O}_{2}\right)$ (Table 2). The highest concentration (5\%) showed the greatest activity against both microorganisms $(P<0.05)$ compared with 1 and/or $2 \%$ dose and compared with the effect of $\mathrm{NaClO}(100 \mathrm{ppm})$. Moreover, the effectiveness of the different doses was equal for both microorganisms $(P>0.05)$. Furthermore, no pathogenic concentrations of $\mathrm{H}_{2} \mathrm{O}_{2}(1-2 \%)$ were not efficient in reducing the bacterial load of the fruit matrix.

For organic acids, reductions of $\geq 2.7 \log \mathrm{CFU} / \mathrm{g}$ were reported for both bacterial strains in all for the treatments with CA, all doses tested presented presence of foodborne pathogens after 
washing. Some works have demonstrated that exceed levels of organic acids would not prevent adverse effects on the sensory quality of produce (Koutsoumanis et al., 2013) and it is demonstrated that $2 \%$ is generally considered as the appropriate concentration of organic acids for reducing Escherichia coli O157:H7, Salmonella Typhimurium, and L. monocytogenes in fruits (Neal et al., 2012; Ramos-Villarroel et al., 2015; Sagong et al., 2011; Salinas-Roca et al., 2016; Wang et al., 2013). Moreover, high concentrations would imply higher costs for their application and therefore, $2.5 \%$ was the concentration selected for organic acids tested in the present study.

\subsubsection{Effect of selected doses on pathogenic bacteria}

All selected treatments ( $80 \mathrm{ppm}$ of PA, $5 \% \mathrm{H}_{2} \mathrm{O}_{2}$ and $2.5 \%$ of organic acids) were tested again together, using the same batch of strawberries, storage conditions and inoculum. The inoculum level of fresh strawberries with tested bacterial strains was ca. 4.40 and $4.70 \log \mathrm{CFU} / \mathrm{g}$ for $L$. monocytogenes and S. enterica, respectively (data not shown). After all washing treatments, bacteria populations were statistically lower than the initial population (Fig. 1). For both S. enterica and L. monocytogenes strains, ca. $2.0 \log$ of the pathogens were removed from the surface of fresh strawberries by $100 \mathrm{ppm}$ chlorine washing (control group). Similarly, $>2.0 \log$ reductions could be achieved for both pathogenic bacteria tested with the other alternative sanitizers studied. Therefore, there were no statistical differences among alternative treatments and $\mathrm{NaClO}(100 \mathrm{ppm})$ effect $(P>0.05)$, being potential alternatives for the disinfection of strawberries destined to processing and frozen purposes. Likewise, for both microorganisms, it has been seen that there were no significant differences between L. monocytogenes and Salmonella spp. among the different sanitizers and doses tested.

In strawberries, pathogenic microorganisms have been reported in other investigations to pose a health concern, namely tested microorganisms studied in the present study and Escherichia coli O157:H7 (European Food Safety Authority, 2014) and several disinfectants have been tested for their reduction. For instance, Guo et al. (2018) studied the effect of PA at 90 ppm for 2 min and found a reduction of Salmonella spp. and E. coli O157:H7 of > $1.2 \mathrm{log}$ CFU/g after the washing treatments. Similar results with the present investigation were described by Zhou et al. (2017), 
which used $0.5 \%$ levulinic acid (LVA; organic acid) plus $0.5 \%$ sodium dodecyl sulphate (SDS), achieving $\geq 2.0 \log \mathrm{CFU} / \mathrm{g}$ reductions of L. monocytogenes and Salmonella spp., and $1.8 \log$ CFU/mL of E.coli O157:H7. Gómez-Aldapa et al. (2017) reported that washing with $0.5 \%$ of acetic acid for 10-min caused a significant reduction $(P<0.05)$ in the level of concentration of pathogenic bacteria, including $S$. typhimurium and L. monocytogenes, on fresh strawberries compared to the control with water alone, achieving reductions between 0.8 and $1.4 \log$ CFU/g. However, it has to be under consideration that long processing times that have been studied are not feasible for practical application.

Other environmentally friendly and safe approaches have been developed for the disinfection of fruit and vegetables in the food industry as a possible alternative to chlorine disinfection. These comprise the use of novel chemical strategies, such as electrolyzed oxidizing water (EOW) (Udompijitkul et al., 2007), ozone (Brodowska et al., 2017), or chlorine dioxide (Aday et al., 2014) on strawberries. Physical strategies include high pressure processing (HPP) (Huang et al., 2014), UV-C light alone (Butot et al., 2018), or combined with a photocatalysis technology $\left(\mathrm{TiO}_{2}\right)$ (Lee et al., 2018), or intense pulsed light (IPL) processing (Duarte-Molina et al., 2016). Some of these strategies have suggested that their use in the food industry has potential applications in microbial decontamination (Lafarga et al., 2018).

In wash water counts after the treatments ( $2 \mathrm{~min}$ ), pathogenic bacteria were present in water with organic acids (LA, AA and CA). For LA, $1.91 \log$ CFU/mL of $S$. enterica was found and $L$. monocytogenes was not detected. In case of AA, $2.56 \log$ CFU/g was found for S. enterica and $1.20 \log$ CFU/g for L. monocytogenes. Similar results were reported for CA, with a total of 2.21 $\log \mathrm{CFU} / \mathrm{g}$ and $1.91 \log \mathrm{CFU} / \mathrm{g}$ of S. enterica and L. monocytogenes, respectively. Concerning PA and $\mathrm{H}_{2} \mathrm{O}_{2}$ effect, no population of both microorganisms were found, as in the chlorine treatment (100 ppm). In short, $\mathrm{PA}$ and $\mathrm{H}_{2} \mathrm{O}_{2}$ were more effective to reduce cross-contamination levels in wash water and maintain the water quality during processing compared to organic acids. Furthermore, in comparison with chlorine, PA has less potential of producing undesirable byproducts, which are easily dissolved in water, thus making these sanitizers a good alternative to 
chlorine and for maintain the water washing safe and quality (Banach et al., 2015). The reported ability of PA to reduce biofilm formation would make this product a suitable sanitizer to add in the washing step (Barbosa et al., 2016). On the other hand, $\mathrm{H}_{2} \mathrm{O}_{2}$ had relatively high cost and is not recommended for use in berry produce (bleaching of anthocyanins in berries) (Sapers, 2003). Ramos et al. (2013) found that high concentrations (> $5 \%$ ) of $\mathrm{H}_{2} \mathrm{O}_{2}$ could interfere with the overall quality of the fruit (Beltrán et al., 2005; Ölmez \& Kretzschmar, 2009; Rico et al., 2007). Maintain the $5 \%$ solution of $\mathrm{H}_{2} \mathrm{O}_{2}$ in dump tanks and flumes with a few thousand fruit capacity would require continuous supply of substantial quantities of concentrated $\mathrm{H}_{2} \mathrm{O}_{2}$ (Pietrysiak et al., 2019).

\subsection{Evaluation of chemical sanitizers on the infectivity of MNV-1}

The inoculum of MNV-1, as a human norovirus surrogate, on strawberries reached to $3.8 \log$ $\mathrm{TCID}_{50} / \mathrm{mL}$ (data not shown). Reductions of viral strain were $>1.7 \log \mathrm{TCID}_{50} / \mathrm{mL}$ for all the sanitizers tested (Fig. 2). Viral population removal of different treatments was not statistically different among them, so the efficiency of these sanitizers were equivalent to $\mathrm{NaClO}$ (100 ppm) $(P>0.05)$. Previous publications reported that tap water alone and chlorine solution $(100-200$ ppm) gave < 1.2-log reductions in virus titer on fresh strawberries (Predmore et al., 2011). Baert et al. (2009) found that tap water washing only gave an average reduction of 0.94 logs of MNV1 in shredded lettuce, while the addition of $200 \mathrm{ppm}$ of $\mathrm{NaClO}$ only led to an additional $0.48 \mathrm{logs}$, and the addition of $80 \mathrm{ppm}$ of PA acid brought about a reduction of only $0.77 \mathrm{log}$. Huang et al. (2015) shown the effectiveness of water pulsed-light (WPL) combined with $\mathrm{H}_{2} \mathrm{O}_{2}$ in reducing MNV-1, on berries. For strawberries, WPL $-\mathrm{H}_{2} \mathrm{O}_{2}$ treatment achieved a significantly higher $(P<$ $0.05)$ reduction of MNV-1 than control washing $\left(\mathrm{H}_{2} \mathrm{O}\right)$, by reducing $2.2 \log \mathrm{PFU} / \mathrm{g}$ of MNV-1. Other studies combined $0.5 \%$ levulinic acid (LVA) plus $0.5 \%$ sodium dodecyl sulfate (SDS) wash and obtained $1.40 \log$ reduction for MNV-1, which were comparable with the reductions induced by chlorine (1.5 log reduction) $(P>0.05)$ (Zhou et al., 2017). Other treatments, including short-wave ultraviolet light (UV-C) and gaseous ozone achieved reductions about $<2 \log \mathrm{TCID}_{50}$ of human norovirus in fresh strawberries (Butot et al., 2018; Zhou et al., 2018). The results highlight an urgent need to develop a more effective sanitizer for removal of norovirus from berry 
industry, specially taking account the huge increasing number of people that striving to eat healthier by increasing their ingesting that are at high risk for norovirus contamination. The modest practice of washing raw fruits and vegetables using cold or warm water has been shown to remove some of the bacteria on produce, but studies showing the efficacy of these treatments on enteric viruses are limited (Butot et al., 2018). Natural extracts, such as green tea and grape seed extracts, have also been evaluated as natural sanitizers on fresh vegetables (Randazzo et al., 2017).

\subsection{Evaluation of chemical sanitizers on non-inoculated strawberries}

\subsubsection{Quality changes}

Physicochemical changes in strawberries, $\mathrm{pH}$, TSS contents, TA, firmness and colour are shown in Table 3. Values of these parameters of non-washed strawberries were in concordance with the literature (Ayala-Zavala et al., 2004). Values of TSS and TA contents showed barely statistically significant differences among treatments. Although existing differences between treatments, there was not a general predisposition that explains changes in TSS and TA contents. TA values were higher when strawberries were washed with $100 \mathrm{ppm} \mathrm{NaClO}$ and $\mathrm{CA}$, achieving a maximum of $9.16 \pm 0.04$ and $8.90 \pm 0.29 \mathrm{mg}$ citric acid/L juice, respectively when treatment time was $2 \mathrm{~min}$.

Strawberry colour before any sanitization washing, expressed as CIELab coordinates, was L* $40.76 \pm 3.39, a^{*} 31.96 \pm 1.62$ and $b^{*} 23.26 \pm 4.80$. These values were comparable to those found in previous researches (Van de Velde et al., 2014). Statistical differences among treatments regarding each CIE-Lab coordinates were observed, and PA-washed samples seem to have more luminosity $\left(\mathrm{L}^{*}\right)$ and $\mathrm{H}_{2} \mathrm{O}_{2} 5 \%$ have more $\mathrm{a}^{*}$ value, that indicates the red intensity. Colour is an important visual parameter that influence the consumers' acceptance and buying intention (Barrett et al., 2010). Alexandre et al. (2012) found that microbial loads of strawberries washed with $\mathrm{H}_{2} \mathrm{O}_{2}$ resulted in lower microbial loads but caused significant changes in key attributes such as colour and total anthocyanins content. 
On the other hand, texture was evaluated by firmness test. The obtained results for firmness showed no statistical differences among treatments and initial value. Firmness values were in the range of those reported by previous studies (Duvetter et al., 2005).

\subsubsection{Native microbiota counts}

452

Regarding epiphytic microbiota, the initial concentration was ca. 3.0 - $3.5 \log$ CFU/g on untreated strawberries (Fig. 3). Remaining total aerobic mesophyll (TAM) population after NaClO (100 ppm) washing was $1.7 \pm 0.3 \log \mathrm{CFU} / \mathrm{g}$. Only $\mathrm{NaClO}$, LA and AA treatments were statistically most effective than the other disinfectants compared with the initial population (untreated strawberries). For all treatments, TAM reduction range was between $0.0-1.4 \log \mathrm{CFU} / \mathrm{g}$. The alternative sanitizers effect was comparable to that of $\mathrm{NaClO}(100 \mathrm{ppm})$, as there were no significant differences between populations, except for PA $80 \mathrm{ppm}$. The population reported in the PA treatment was statistically the same as the initial population (untreated). Native microbiota of fruits and vegetables is a complex and heterogenic community. However, dissimilar proportions of each genre of microorganisms and different loads can be found between cultivars, batches or years and even among fruits (Baugher and Jaykus, 2016; Jensen et al., 2013). Hereto, a higher sensitivity to washing procedures depending on the main genres existing in the population may occur, as it has been proved that there are inter-specific differences on how microorganisms are inhibited by this product. PA disrupts the chemiosmotic function of the lipoprotein cytoplasmic membrane and rupture the cell walls promoting catalase inactivation, so variances in membrane composition and bacteria heterogenicity of TAM could be a reason for comparative sensitivity among PA (Banach et al., 2015).

For fungi, significant reductions were found on mould and yeast (M\&Y) populations among some treatments compared with the initial population (untreated strawberries), except for PA, LA and CA sanitizers (Fig. 3). The most effective treatments for $\mathrm{M} \& \mathrm{Y}$ reduction were the $\mathrm{NaClO}, \mathrm{H}_{2} \mathrm{O}_{2}$ and AA treatments. M\&Y reduction range was between $0.3-1.8 \log \mathrm{CFU} / \mathrm{g}$. Previous publications reported maximum TAM reductions of $1.5 \log \mathrm{CFU} / \mathrm{g}$ in berries when using citric or malic acid, whereas M\&Y reductions below 1 log CFU/g were achieved (Wei et al., 2017). 
475 Microbial contamination of washing solutions after disinfection changing between 1.7 and 3.2

$476 \log \mathrm{CFU} / \mathrm{mL}$ (Fig. 3), except for $\mathrm{NaClO}$ and $\mathrm{H}_{2} \mathrm{O}_{2} 5 \%$, in which both TAM and M\&Y were

477 reduced completely.

\section{4. Conclusion}

479 For each treatment, different concentrations were studied in order to optimize the decontamination

480 washing step with chemical sanitizers. The best concentrations were $80 \mathrm{ppm}$ for PA, $5 \%$ for $\mathrm{H}_{2} \mathrm{O}_{2}$

481 and $2.5 \%$ for organic acids after 2 min treatment. Results indicate that the sanitizers selected may

482 be a feasible alternative to chlorine (100 ppm) for removing pathogenic microorganisms from

483 fresh strawberries destined to frozen and processing purposes, reducing the number of produce-

484 related food-borne outbreaks. Despite good results were also obtained with $\mathrm{H}_{2} \mathrm{O}_{2}$, we opt for PA

485 as a good alternative to chlorine disinfection against microbial pathogens. PA at $80 \mathrm{ppm}$ gave

486 reductions of $3.5 \log$-reduction for L. monocytogenes, $2.6 \log$-reduction for S. enterica, and 1.9

487 log-reduction for MNV-1. Additionally, no remaining population of pathogenic bacteria was

488 detected after PA sanitization in wash water, thus preventing possible subsequent cross-

489 contamination. This sanitizer does not form undesirable by-products derived from chlorine and

490 did not affect the physicochemical quality of strawberries. Furthermore, PA is used in less

491 quantity compared with the other sanitizers. To improve PA implementation, its combination with

492 other chemical/physical technologies, such as the combination with water-assisted ultraviolet

493 (UV-C) light, should be investigated. 
496 The authors are grateful to the Spanish Government (Ministerio de Economía y Competitividad, 497 research projects FRESAFE AGL2016-78086-R and TECALZIM RTC-2016-5498-2) and the 498 CERCA Programme of 'Generalitat de Catalunya' for its financial support. J. Ortiz-Solà thanks 499 the University of Lleida for its PhD grant (BOU186 - 243/2017 UdL) and M. Anguera for their 500 technician support.

\section{Conflict of interest}

502 The authors declare no conflict of interest. 
Abadias, M., Usall, J., Anguera, M., Solsona, C., \& Viñas, I. 2008. Microbiological quality of fresh, minimally-processed fruit and vegetables, and sprouts from retail establishments. Int. J. Food Microbiol., 123(1-2), 121-129. https://doi.org/10.1016/j.ijfoodmicro.2007.12.013.

Aday, M. S., \& Caner, C. 2014. Individual and combined effects of ultrasound, ozone and chlorine dioxide on strawberry storage life. LWT - Food Sci. Technol., 57(1), 344351. http://doi:10.1016/j.lwt.2014.01.006

Alexandre, E. M. C., Brandão, T. R. S., \& Silva, C. L. M. 2012. Efficacy of non-thermal technologies and sanitizer solutions on microbial load reduction and quality retention of strawberries. J. Food Eng., 108, 417-426.

Artes F, Gomez P, Aguayo E, Escalona V, Artes-Hernandez F. 2009. Sustainable sanitation techniques for keeping quality and safety of fresh-cut plant commodities. Postharvest Biol. Technol. 51:287-296. https://doi.org/10.1016/j.postharvbio.2008.10.003

Ayala-Zavala, J.F., Wang, S.Y., Wang, C.Y., González-Aguilar, G.A., 2004. Effect of storage temperatures on antioxidant capacity and aroma compounds in strawberry fruit. LWT - Food Sci. Technol. 37, 687-695. https://doi.org/10.1016/j.lwt.2004.03.002.

Baert, L., Mattison, K., Loisy-Hamon, F., Harlow, J., Martyres, A., Lebeau, B., \& Uyttendaele, M. 2011. Review: Norovirus prevalence in Belgian, Canadian and French fresh produce: A threat to human health? Int. J. Food Microbiol., 151(3), 261-269. https://doi.org/10.1016/j.ijfoodmicro.2011.09.013.

Baert, L., Vandekinderen, I., Devlieghere, F., Van Coillie, E., Debevere, J., Uyttendaele, M., (2009). Efficacy of sodium hypochlorite and peroxyacetic acid to reduce murine norovirus 1, B40-8, Listeria monocytogenes and Escherichia coli O157:H7 on shredded iceberg lettuce and in residual wash water. J. Food Prot. 72, 1047-1054.

Banach, K., Sampers, I., Van Haute, S., van der, H.J., F.-K, 2015. Effect of disinfectants on preventing the cross-contamination of pathogens in fresh produce washing water. Int. J. Environ. Res. Public Health 12, 8658-8677. https://doi.org/10.3390/ijerph120808658.

Barbosa, J., Grzybpwski, V., Cuppini, M., Flach, J., Steffens, C., 2016. Listeria monocytogenes adhesion to food processing surfaces (boning knives) and the removal efficacy of different sanitizers. Int. J. Food Sci. 28, 733-743. https://doi.org/10.14674/1120-1770/ijfs.v109.

Barrett, D.M., Beaulieu, J.C., Shewfelt, R., 2010. Color, flavor, texture, and nutritional quality of fresh-cut fruits and vegetables: desirable levels, instrumental and sensory measurement, and 
the effects of processing. Crit. Rev. Food Sci. Nutr. 50, 369-389. https://doi.org/10.1080/10408391003626322.

Baugher, J.L., Jaykus, L.A., 2016. Natural microbiota of raspberries (Rubus idaeus) and strawberries (Fragaria x ananassa): microbial survey, bacterial isolation and identification, and biofilm characterization. Acta Hortic. (Wagening.) 1133, 521-526. https://doi.org/10.17660/ActaHortic.2016.1133.82.

Beltrán, D., Selma, M. V., Tudela, J. A., \& Gil, M. I. 2005. Effect of different sanitizers on microbial and sensory quality of fresh-cut potato strips stored under modified atmosphere or vacuum packaging. Postharvest Biol. Technol., 37(1), 37-46. https://doi.org/10.1016/j.postharvbio.2005.02.010

Beuchat, L. R. 1995. Pathogenic microorganisms associated with fresh produce. J. Food Prot., 59, 204-216.

Bozkurt, H., Phan-Thien, K., Van Ogtrop, F., Bell, T., Mcconchie, R. 2020. Outbreaks, occurrence, and control of norovirus and hepatitis a virus contamination in berries: A review. Crit. Re. Food sci, 1-22.https://10.1080/10408398.2020.1719383

Brodowska, A. J., Nowak, A., \& Śmigielski, K. 2017. Ozone in the food industry: Principles of ozone treatment, mechanisms of action, and applications: An overview. Cri. Rev. Food Sci. Nutr., 1-26. http://doi:10.1080/10408398.2017.1308313

Butot, S., Cantergiani, F., Moser, M., Jean, J., Lima, A., Michot, L., Putallaz, T., \& Zuber, S. 2018. UV-C inactivation of foodborne bacterial and viral pathogens and surrogates on fresh and frozen berries. Int. J. Food Microbiol., 275, 8-16. https://doi:10.1016/j.ijfoodmicro.2018.03.016

Cook, N., Knight, A., \& Richards, G. P. 2016. Persistence and elimination of human norovirus in food and on food contact surfaces: A critical review. J. Food Prot, 79(7), 1273-1294. https://doi:10.4315/0362-028x.jfp-15-570.

De Villiers, M. M., Wurster, D. E., \& Narsai, K. 1997. Stability of lactic acid and glycolic acid in aqueous systems subjected to acid hydrolysis and thermal decomposition. $J$ Soc Cosmet Chem, 48(4), 165-174.

del Carmen Velázquez, L., Barbini, N. B., Escudero, M. E., Estrada, C. L., \& de Guzmán, A. M. S. 2009. Evaluation of chlorine, benzalkonium chloride and lactic acid as sanitizers for reducing Escherichia coli O157: H7 and Yersinia enterocolitica on fresh vegetables. Food Control, 20( 3), 262-268. https://doi.org/10.1016/j.foodcont.2008.05.012

Delbeke, S., Ceuppens, S., Hessel, C. T., Castro, I., Jacxsens, L., De Zutter, L., \& Uyttendaele, 
M. 2015. Microbial safety and sanitary quality of strawberry primary production in Belgium: Risk factors for Salmonella and shiga toxin-producing Escherichia coli contamination. Appl Environ Microbiol, 81(7), 2562-2570. https://doi.org/10.1128/AEM.03930-14.

Duarte-Molina, F., Gómez, P. L., Castro, M. A., \& Alzamora, S. M. 2016. Storage quality of strawberry fruit treated by pulsed light: Fungal decay, water loss and mechanical properties. Innov. Food Sci. Emerg. Technol., 34, 267-274. http://doi:10.1016/j.ifset.2016.01.019

Duvetter, T., Fraeye, I., Van Hoang, T., Van Buggenhout, S., Verlent, I., Smout, C., Van Loey, A., Hendrickx, M., 2005. Effect of pectinmethylesterase infusion methods and processing techniques on strawberry firmness. J. Food Sci. 70, 383-388. https://doi.org/10.1111/j.1365-2621.2005.tb11460.x.

EFSA, Panel on Biological Hazards, 2014. Scientific Opinion on the risk posed by pathogens in food of non-animal origin. Part 2 (Salmonella and Norovirus in berries). EFSA J. 12, 3706. https://doi.org/10.2903/j.efsa.2014.3706.

Falcó, I., Randazzo, W., Gómez-Mascaraque, L.G., Aznar, R., López-Rubio, A., Sánchez, G. 2018. Fostering the antiviral activity of green tea extract for sanitizing purposes through controlled storage conditions. Food Control, 84, 485-492. https://doi.org/10.1016/j.foodcont.2017.08.037

Gómez-Aldapa, C. A., Portillo-Torres, L. A., Villagómez-Ibarra, J. R., Rangel-Vargas, E., TéllezJurado, A., Cruz-Gálvez, A. M., \& Castro-Rosas, J. 2017. Survival of foodborne bacteria on strawberries and antibacterial activities of Hibiscus sabdariffa extracts and chemical sanitizers on strawberries. J. Food Safety, 38(1), e12378. http://doi:10.1111/jfs.12378

Guo, M., Jin, T.Z., Gurtler, J.B., Fan, X., Yadav, M.P., 2018. Inactivation of Escherichia coli O157:H7 and Salmonella and native microbiota on fresh strawberries by antimicrobial washing and coating. J. Food Prot. 81, 1227-1235. https://doi.org/10.4315/0362-028X.JFP18-007.

Harris, L. J., Farber, J. N., Beuchat, L. R., Parish, M. E., Suslow, T. V., Garrett, E. H., \& Busta, F. F. 2003. Outbreaks associated with fresh produce: Incidence, growth, and survival of pathogens in fresh and fresh-cut produce. Compr Rev Food Sci F, 2(s1), 78-141. https://doi:10.1111/j.1541-4337.2003.tb00031.x.

Huang, R., Li, X., Huang, Y., \& Chen, H. 2014. Strategies to enhance high pressure inactivation of murine norovirus in strawberry puree and on strawberries. Int. J. food microbiol., 185, 16. http://doi.org/10.1016/j.ijfoodmicro.2014.05.007.

Huang, Y., \& Chen, H. 2015. Inactivation of Escherichia coli O157:H7, Salmonella and human 

norovirus surrogate on artificially contaminated strawberries and raspberries by waterassisted pulsed light treatment. Int. Food Res. J., 72, 1-7. https://doi.org/10.1016/j.foodres.2015.03.013

Janowicz, M., Lenart, A., Idzikowska, W., 2007. Sorption properties of osmotically dehydrated and freeze-dried strawberries. Pol. J. Food Nutr. Sci. 57 (1), 69-76.

Jensen, B., Knudsen, I. M. B., Andersen, B., Nielsen, K. F., Thrane, U., Jensen, D. F., \& Larsen, J. 2013. Characterization of microbial communities and fungal metabolites on field grown strawberries from organic and conventional production. Int. J. Food Microbiol, 160(3), 313322. https://doi.org/10.1016/j.ijfoodmicro.2012.11.005.

Koutsoumanis K., Skandamis P. 2013. New research on organic acids and pathogen behaviour. In: Sofos J., editor. Advances in Microbial Food Safety. 1st ed. Volume 1. Woodhead Publishing; Cambridge, UK. pp. 355-384.

Lafarga, T., Colás-Medà, P., Abadias, M., Aguiló-Aguayo, I., Bobo, G., \& Viñas, I. 2019. Strategies to reduce microbial risk and improve quality of fresh and processed strawberries: A review. Innov. Food Sci. Emerg. Technol. https://doi:10.1016/j.ifset.2018.12.012.

Lee, M., Shahbaz, H. M., Kim, J. U., Lee, H., Lee, D.-U., \& Park, J. 2018. Efficacy of UV-TiO 2 photocatalysis technology for inactivation of Escherichia coli $\mathrm{K} 12$ on the surface of blueberries and a model agar matrix and the influence of surface characteristics. Food Microbiol., 76, 526-532. http://doi:10.1016/j.fm.2018.07.015

Lynch, K. M., Zannini, E., Wilkinson, S., Daenen, L., \& Arendt, E. K. 2019. Physiology of acetic acid bacteria and their role in vinegar and fermented beverages. Compr. Rev. Food Sci. Food Saf. https://doi:10.1111/1541-4337.12440.

Meireles, A., Giaouris, E., Simões, M., 2016. Alternative disinfection methods to chlorine for use in the fresh-cut industry. Food Res. Int. 82, 71-85. https://doi.org/10.1016/j. foodres.2016.01.021.

Mezzetti, B., Balducci, F., Capocasa, F., Cappelletti, R., Mazzoni, L., Giampieri, F., \& Battino, M. 2014. Can we breed a healthier strawberry and claim it? Acta Hort, 117, 7-14.

Miller, F. A., Ramos, B., Gil, M. M., Brandão, T. R. S., Teixeira, P., \& Silva, C. L. M. 2009. Influence of $\mathrm{pH}$, type of acid and recovery media on the thermal inactivation of Listeria innocua. Int. J. Food Microbiol, 133(1-2), 121128. https://doi:10.1016/j.ijfoodmicro.2009.05.007.

Neal, J. A., Marquez-Gonzalez., M., Cabrera-Diaz, E., Lucia, L. M., O’Bryan, C. A., et al. 2012. Comparison of multiple chemical sanitizers for reducing Salmonella and Escherichia coli 

10.1016/j.foodres.2011.04.011.

Nicolau-Lapeña, I., Abadias, M., Bobo, G., Aguiló-Aguayo, I., Lafarga, T., \& Viñas, I. 2019. Strawberry sanitization by peracetic acid washing and its effect on fruit quality. Food Microbiol. https://doi:10.1016/j.fm.2019.05.004.

Ölmez, H., \& Kretzschmar, U. 2009. Potential alternative disinfection methods for organic freshcut industry for minimizing water consumption and environmental impact. LWT - Food Sci. Technol., 42(3), 686-693. https://doi:10.1016/j.lwt.2008.08.001.

Ortiz-Solà, J., Valero, A., Viñas, I., Colás-Medà, P., \& Abadias, M. 2019b. Microbial interaction between Salmonella enterica and main postharvest fungal pathogens on strawberry fruit. Int. J. Food Microbiol, in press. https://doi:10.1016/j.ijfoodmicro.2019.108489

Ortiz-Solà, J., Viñas, I., Colás-Medà, P., Anguera, M., \& Abadias, M. 2019a. Occurrence of selected viral and bacterial pathogens and microbiological quality of fresh and frozen strawberries sold in Spain. Int. J. Food Microbiol, in press. https://doi:10.1016/j.ijfoodmicro.2019.108392.

Pablos, C., Romero, A., De Diego, A., Vargas, C., Bascón, I., Pérez-Rodríguez, F., Marugán, J., 2018. Novel antimicrobial agents as alternative to chlorine with potential applications in the fruit and vegetable processing industry. Int. J. Food Microbiol. 285, 92-97. https://doi.org/10.1016/j.ijfoodmicro.2018.07.029.

Palumbo, Mary \& Harris, Linda \& Danyluk, Michelle. 2013. Survival of Foodborne Pathogens on Berries. Publication FSHN13-12; University of Florida, Institute of Food and Agricultural Sciences: Gainesville, FL, USA, 2013. Available online: https://edis.ifas.ufl.edu/pdffiles/FS/FS23600.pdf (accessed on July 27, 2020).

Pietrysiak, E., Smith, S., \& Ganjyal, G. M. 2019. Food safety interventions to control Listeria monocytogenes in the fresh apple packing industry: A review. Compr. Rev. Food Sci. Food Saf. 1-22. https://doi:10.1111/1541-4337.12496

Pintó, R.M., Diez, J.M. and Bosch, A. 1994. Use of the colonic carcinoma cell line CaCo-2 for in vivo amplification and detection of enteric viruses. $J$ Med Virol 44, 310-315. https://doi:10.1002/jmv.1890440317

Predmore, A., \& Li, J. 2011. Enhanced removal of a human norovirus surrogate from fresh vegetables and fruits by a combination of surfactants and sanitizers. Appl Environ Microbiol, 77(14), 4829-4838. https://doi:10.1128/aem.00174-11. 
Ramos, B., Miller, F. A., Brandão, T. R. S., Teixeira, P., \& Silva, C. L. M. 2013. Fresh fruits and vegetables-An overview on applied methodologies to improve its quality and safety. Innov. Food Sci. Emerg. Technol., 20, 1-15. https://doi.org/10.1016/j.ifset.2013.07.002

Ramos-Villarroel, A. Y., Martín-Belloso, O., and Soliva-Fortuny, R. 2015. Combined effects of malic acid dip and pulsed light treatments on the inactivation of Listeria innocua and Escherichia coli on fresh-cut produce. Food Control 52, 112-118. https://doi: 10.1016/j.foodcont.2014.12.020.

Randazzo, W., Falcó, I., Aznar, R., Sánchez, G. 2017. Effect of green tea extract on enteric viruses and its application as natural sanitizer. Food Micro., 66, 150-156. https://doi:10.1016/j.fm.2017.04.018.

Rico, D., Martin-Diana, A. B., Barat, J. M., \& Barry-Ryan, C. 2007. Extending and measuring the quality of fresh-cut fruit and vegetables: A review. Trends Food Sci. Technol., 18(7), 373-386. https://doi.org/10.1016/j.tifs.2007.03.011

Sagong, H. G., Lee, S. Y., Chang, P. S., Heu, S., Ryu, S., Choi, Y. J., et al. 2011. Combined effect of ultrasound and organic acids to reduce Escherichia coli O157:H7, Salmonella Typhimurium, and Listeria monocytogenes on organic fresh lettuce. Int. J. Food Microbiol. 145, 287-292. https://doi: 10.1016/j.ijfoodmicro.2011.01.010.

Salinas-Roca, B., Soliva-Fortuny, R., Welti-Chanes, J., and Martín-Belloso, O. 2016. Combined effect of pulsed light, edible coating and malic acid dipping to improve fresh-cut mango safety and quality. Food Control 66, 190-197. https://doi: 10.1016/j.foodcont.2016.02.005

Sánchez, G., Aznar, R., Martínez, A., Rodrigo, D. 2011. Inactivation of human and murine norovirus by high-pressure processing. Foodborne Pathog. Dis., 8(2), 249-253. https://doi:10.1089/fpd.2010.0667.

Sapers, G. M. 2003. Washing and sanitizing raw materials for minimally processed fruit and vegetable products. Boca Raton, FL: CRC Press.

Singh, P., Hung, Y.C., Qi, H., 2018. Efficacy of peracetic acid in inactivating foodborne pathogens on fresh produce surface. J. Food Sci. 83, 432-439. https://doi.org/10.1111/17503841.14028 .

Siro, I., Devlieghere, F., Jacxsens, L., Uyttendaele, M., \& Debevere, J. 2006. The microbial safety of strawberry and raspberry fruits packaged in high-oxygen and equilibrium-modified atmospheres compared to air storage. Int. J. Food Sci. Tech., 41(1), 93-103. https://doi:10.1111/j.1365-2621.2005.01046.x.

Sreedharan, A., Tokarskyy, O., Sargent, S., \& Schneider, K. R. 2015. Survival of Salmonella spp. 
on surface-inoculated forced-air cooled and hydrocooled intact strawberries, and in strawberry puree. Food Control, 51, 244-250. https://doi:10.1016/j.foodcont.2014.11.042.

Trevisani, M., Berardinelli, A., Cevoli, C., Cecchini, M., Ragni, L., \& Pasquali, F. (2017). Effects of sanitizing treatments with atmospheric cold plasma, SDS and lactic acid on verotoxinproducing Escherichia coli and Listeria monocytogenes in red chicory (radicchio). Food Control, 78, 138-143. https://doi:10.1016/j.foodcont.2017.02.056.

Udompijitkul, P., Daeschel, M. A., \& Zhao, Y. 2007. Antimicrobial effect of electrolyzed oxidizing water against Escherichia coli $\mathrm{O} 157: \mathrm{H} 7$ and Listeria monocytogenes on fresh strawberries (Fragaria $\times$ ananassa). J. Food Sci., $\quad 72(9), \quad$ M397M406. http://doi:10.1111/j.1750-3841.2007.00531.x

Van de Velde, F., Güemes, D. R., \& Pirovani, M. E. 2014. Optimisation of the peracetic acid washing disinfection of fresh-cut strawberries based on microbial load reduction and bioactive compounds retention. Int. J. Food Sci. Tech., 49, 634-640. https://doi.org/10.1111/ijfs.12346.

Velickova, E., Tylewicz, U., Dalla Rosa, M., Winkelhausen, E., Kuzmanova, S., \& Romani, S. 2018. Effect of pulsed electric field coupled with vacuum infusion on quality parameters of $\begin{array}{lllll}\text { frozen/thawed } \quad \text { strawberries. } \quad J . & \text { Food }\end{array}$ 64. http://doi:10.1016/j.jfoodeng.2018.03.030

Wang, C., Wang, S., Chang, T., Shi, L., Yang, H., Shao, Y. 2013. Efficacy of lactic acid in reducing foodborne pathogens in minimally processed lotus sprouts. Food Control 30, $721-$ 726. https://doi: 10.1016/j.foodcont.2012. 08.024.

Wang, H., Ryser, E.T., 2014. Efficacy of various sanitizers against Salmonella during simulated commercial packing of tomatoes. J. Food Prot. 77, 1868-1875. https://doi.org/10.4315/0362-028x.jfp-14-213.

Wei, W., Wang, X., Xie, Z., Wang, W., Xu, J., Liu, Y., Gao, H., Zhou, Y. 2017. Evaluation of sanitizing methods for reducing microbial contamination on fresh strawberry, cherry tomato, and red bayberry. Front. Microbiol. 8, 1-11. https://doi.org/10.3389/fmicb.2017.02397.

Wessels, S., Ingmer, H., 2013. Modes of action of three disinfectant active substances: a review. Regul. Toxicol. Pharmacol. 67, 456-467. https://doi.org/10.1016/j.yrtph.2013.09.006.

Zhou, Z., Zuber, S., Cantergiani, F., Butot, S., Li, D., Stroheker, T., Uyttendaele, M. 2017. Inactivation of viruses and bacteria on strawberries using a levulinic acid plus sodium dodecyl sulfate based sanitizer, taking sensorial and chemical food safety aspects into 

account. Int. J. Food Microbiol., 257, 176-182. https://10.1016/j.ijfoodmicro.2017.06.023.

733 Zhou, Z., Zuber, S., Cantergiani, F., Sampers, I., Devlieghere, F., Uyttendaele, M. 2018. 734 Inactivation of foodborne pathogens and their surrogates on fresh and frozen strawberries using gaseous ozone. Front. Sustain. Food Syst., 2:51. https://doi:10.3389/fsufs.2018.00051.

737 
Table 1. Wash water parameters $(\mathrm{pH}$, oxidation reduction potential (ORP) and concentration of sanitizer). Values are the mean of the 6 repetitions \pm standard deviation. $\mathrm{NaClO}$, sodium hypochlorite; PA, peracetic acid; LA, lactic acid; AA, acetic acid; CA, 741 citric acid.

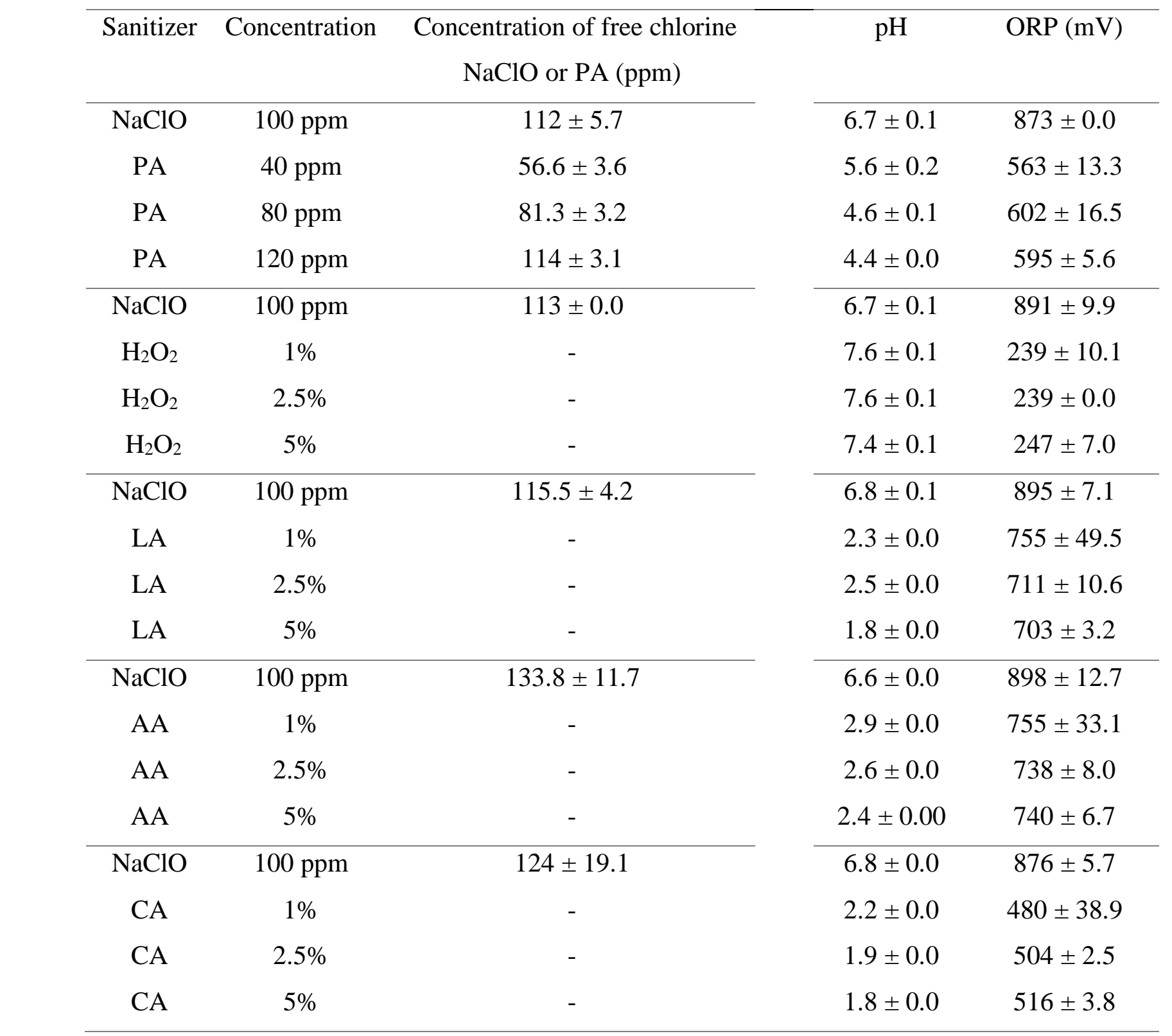




\begin{tabular}{|c|c|c|c|c|c|}
\hline & & \multicolumn{2}{|c|}{ L. monocytogenes } & \multicolumn{2}{|c|}{ Salmonella spp. } \\
\hline & & Strawberry & Water & Strawberry & Water \\
\hline \multirow[t]{3}{*}{ PA } & $40 \mathrm{ppm}$ & $3.8 \pm 0.0^{\mathrm{a}}$ & $\leq \mathbf{1 . 7}$ & $4.1 \pm 0.0^{\mathrm{a}}$ & $\leq 1.7$ \\
\hline & $80 \mathrm{ppm}$ & $3.8 \pm 0.0^{\mathrm{a}}$ & 0.0 & $4.1 \pm 0.0^{\mathrm{a}}$ & 0.0 \\
\hline & $120 \mathrm{ppm}$ & $3.8 \pm 0.0^{\mathrm{a}}$ & 0.0 & $4.1 \pm 0.0^{\mathrm{a}}$ & 0.0 \\
\hline $\mathrm{NaClO}$ & 100 ppm & $2.4 \pm 0.1^{b}$ & 0.0 & $2.3 \pm 0.1^{b}$ & 0.0 \\
\hline \multirow[t]{3}{*}{$\mathrm{H}_{2} \mathrm{O}_{2}$} & $1 \%$ & $2.4 \pm 0.9^{c}$ & 2.7 & $2.3 \pm 0.4^{c}$ & 3.1 \\
\hline & $2.5 \%$ & $3.8 \pm 0.7^{\mathrm{b}}$ & 0.0 & $3.8 \pm 0.9^{\mathrm{b}}$ & 0.0 \\
\hline & $5 \%$ & $5.4 \pm 0.8^{\mathrm{a}}$ & 0.0 & $4.9 \pm 0.0^{\mathrm{a}}$ & 0.0 \\
\hline $\mathrm{NaClO}$ & $100 \mathrm{ppm}$ & $2.9 \pm 0.4^{\mathrm{bc}}$ & 0.0 & $2.7 \pm 0.4^{\mathrm{bc}}$ & 0.0 \\
\hline \multirow[t]{3}{*}{ LA } & $1 \%$ & $2.7 \pm 0.6^{\mathrm{a}}$ & $\leq 1.7$ & $2.7 \pm 0.6^{\mathrm{a}}$ & 2.0 \\
\hline & $2.5 \%$ & $3.0 \pm 0.0^{\mathrm{a}}$ & 0.0 & $2.9 \pm 0.6^{\mathrm{a}}$ & 0.0 \\
\hline & $5 \%$ & $2.7 \pm 0.9^{\mathrm{a}}$ & 0.0 & $2.8 \pm 0.8^{\mathrm{a}}$ & 0.0 \\
\hline $\mathrm{NaClO}$ & 100 ppm & $1.3 \pm 0.4^{\mathrm{b}}$ & 0.0 & $1.2 \pm 0.4^{\mathrm{b}}$ & 0.0 \\
\hline \multirow[t]{3}{*}{$\mathrm{AA}$} & $1 \%$ & $2.4 \pm 0.6^{\mathrm{a}}$ & 0.0 & $3.1 \pm 0.6^{b}$ & $\leq 1.7$ \\
\hline & $2.5 \%$ & $2.5 \pm 0.6^{\mathrm{a}}$ & 0.0 & $3.2 \pm 0.0^{\mathrm{ab}}$ & 0.0 \\
\hline & $5 \%$ & $2.8 \pm 0.6^{\mathrm{a}}$ & 0.0 & $3.9 \pm 0.6^{\mathrm{a}}$ & 0.0 \\
\hline $\mathrm{NaClO}$ & $100 \mathrm{ppm}$ & $3.2 \pm 0.3^{\mathrm{a}}$ & 0.0 & $2.9 \pm 0.3^{b}$ & 0.0 \\
\hline \multirow[t]{3}{*}{$\mathrm{CA}$} & $1 \%$ & $3.2 \pm 0.2^{\mathrm{a}}$ & $\leq 1.7$ & $3.3 \pm 0.4^{\mathrm{ab}}$ & 2.0 \\
\hline & $2.5 \%$ & $4.0 \pm 0.6^{\mathrm{a}}$ & 2.5 & $3.8 \pm 0.6^{\mathrm{a}}$ & 2.8 \\
\hline & $5 \%$ & $4.2 \pm 0.6^{\mathrm{a}}$ & $\leq 1.7$ & $3.8 \pm 0.0^{\mathrm{a}}$ & $\leq 1.7$ \\
\hline
\end{tabular}


$\mathrm{NaClO}$

$100 \mathrm{ppm}$

$2.7 \pm 0.4^{\mathrm{a}}$

0.0

$2.5 \pm 0.4^{\mathrm{b}}$

0.0

745 Table 2. Average reductions (log Colony-forming unit (CFU)/g) of L. monocytogenes

746 and $S$. enterica after 2 minutes on strawberries. Means \pm standard deviation followed by

747 the same small letter indicate no significant differences among the different concentration

748 tested for each treatment $(\mathrm{p} \leq 0.05 ; \mathrm{n}=6)$. For washing solutions, values represent the

TA

Firmness $\quad$ (g citric

$\begin{array}{llll}\mathrm{pH} & (\mathrm{N}) \quad \mathrm{acid} / \mathrm{L} \text { juice }) & \mathrm{TSS}\left({ }^{\circ} \mathrm{B}\right) & \text { Colour }\end{array}$

\begin{tabular}{cccccccc} 
& & & & $\mathrm{L}^{*}$ & $\mathrm{a}^{*}$ & $\mathrm{~b}^{*}$ \\
\cline { 6 - 7 } Initial & $3.49 \pm 0.19^{\mathrm{a}}$ & $3.61 \pm 1.57^{\mathrm{a}}$ & $9.84 \pm 0.91^{\mathrm{a}}$ & $7.80 \pm 0.00^{\mathrm{e}}$ & $40.76 \pm 3.39^{\mathrm{ab}}$ & $31.96 \pm 1.62^{\mathrm{ab}}$ & $23.26 \pm 4.80^{\mathrm{a}}$ \\
$\mathrm{NaClO} 100$ & $3.46 \pm 0.02^{\mathrm{a}}$ & $4.27 \pm 1.88^{\mathrm{a}}$ & $9.16 \pm 0.04^{\mathrm{ab}}$ & $8.07 \pm 0.06^{\mathrm{d}}$ & $43.61 \pm 5.40^{\mathrm{ab}}$ & $31.31 \pm 2.19^{\mathrm{ab}}$ & $28.99 \pm 7.01^{\mathrm{a}}$ \\
$\mathrm{PA} 80$ & $3.61 \pm 0.22^{\mathrm{a}}$ & $4.33 \pm 1.56^{\mathrm{a}}$ & $8.10 \pm 0.06^{\mathrm{bc}}$ & $7.93 \pm 0.05^{\mathrm{de}}$ & $45.48 \pm 2.7^{\mathrm{a}}$ & $31.16 \pm 1.22^{\mathrm{ab}}$ & $30.17 \pm 4.25^{\mathrm{a}}$ \\
$\mathrm{H}_{2} \mathrm{O}_{2} 5 \%$ & $3.42 \pm 0.04^{\mathrm{a}}$ & $3.38 \pm 0.97^{\mathrm{a}}$ & $8.19 \pm 0.18^{\mathrm{bc}}$ & $8.53 \pm 0.05^{\mathrm{c}}$ & $43.16 \pm 0.79^{\mathrm{ab}}$ & $33.53 \pm 0.74^{\mathrm{a}}$ & $27.46 \pm 1.8^{\mathrm{a}}$ \\
$\mathrm{LA} \mathrm{2.5 \%}$ & $3.49 \pm 0.13^{\mathrm{a}}$ & $3.45 \pm 1.26^{\mathrm{a}}$ & $7.86 \pm 0.36^{\mathrm{c}}$ & $9.26 \pm 0.05^{\mathrm{a}}$ & $41.86 \pm 4.09^{\mathrm{ab}}$ & $31.53 \pm 0.88^{\mathrm{ab}}$ & $24.43 \pm 4.49^{\mathrm{a}}$ \\
$\mathrm{AA} 2.5 \%$ & $3.56 \pm 0.06^{\mathrm{a}}$ & $3.11 \pm 0.47^{\mathrm{a}}$ & $8.04 \pm 0.56^{\mathrm{bc}}$ & $9.00 \pm 0.00^{\mathrm{b}}$ & $38.35 \pm 2.64^{\mathrm{b}}$ & $30.11 \pm 1.25^{\mathrm{b}}$ & $21.25 \pm 3.64^{\mathrm{a}}$ \\
$\mathrm{CA} 2.5 \%$ & $3.43 \pm 0.09^{\mathrm{a}}$ & $3.65 \pm 1.21^{\mathrm{a}}$ & $8.90 \pm 0.29^{\mathrm{abc}}$ & $9.46 \pm 0.23^{\mathrm{a}}$ & $42.65 \pm 4.08^{\mathrm{ab}}$ & $31.91 \pm 2.5^{\mathrm{ab}}$ & $27.3 \pm 4.51^{\mathrm{a}}$ \\
\hline
\end{tabular}

749 population of pathogenic bacteria, and were obtained from one sample and repeated

750 twice. $\mathrm{NaClO}$, sodium hypochlorite; PA, peracetic acid; LA, lactic acid; AA, acetic acid;

751 CA, citric acid.

752 Table 3. Values of $\mathrm{pH}$, firmness, titratable acidity (TA), total soluble solids (TSS) and

753 colour $\left(\mathrm{L}^{*}, \mathrm{a}^{*}\right.$ and $\left.\mathrm{b}^{*}\right)$ of strawberries for each washing treatment. Values are expressed

754 as the mean of 6 reps \pm standard deviation. Different letters indicate statistically

755 significant differences $(\mathrm{p}<0.05)$ among treatments. Sodium hypochlorite $(\mathrm{NaClO})$,

756 peracetic acid (PA), lactic acid (LA), acetic acid (AA) and citric acid (CA).

757

*Different letters indicate statistically significant differences $(p<0.05)$ among doses.

758 
Figure 1. Reduction of L. monocytogenes in strawberries (grey bars, log Colony-forming

760

761

762

763

764

765

766 unit (CFU)/g) and Salmonella enterica (white bars, log CFU/g). Population of $L$. monocytogenes in water $(\bullet, \log \mathrm{CFU} / \mathrm{mL})$ and Salmonella enterica $(\boldsymbol{\Delta}, \log \mathrm{CFU} / \mathrm{mL})$.

62 Bacterial reduction 9999values in strawberries are the mean of 6 reps \pm standard deviation. Remaining bacterial population values in water were obtained from one sample for each microorganism and were repeated twice. The straight line indicates the detection limit (dl) of the bacterial population on strawberries. $\mathrm{NaClO}$, sodium hypochlorite; PA, peracetic acid; LA, lactic acid; AA, acetic acid; CA, citric acid.

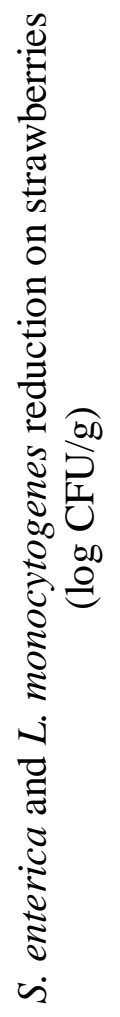

767

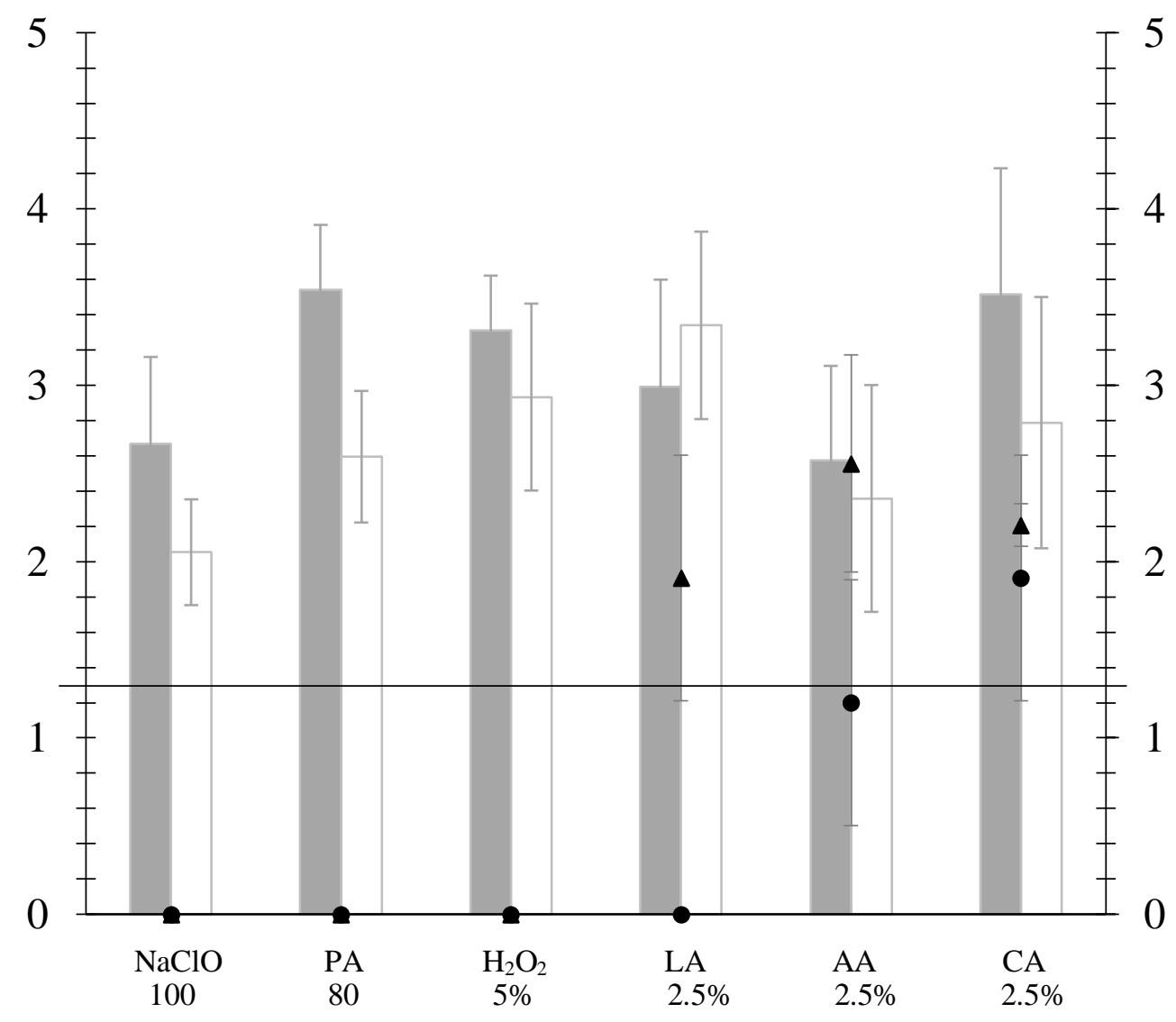


774 Figure 2. Reduction of the infectivity of murine norovirus (MNV-1) in fresh strawberries $775\left(\log 50 \%\right.$ Tissue Culture Infectious Dose $\left.\left(\mathrm{TCID}_{50}\right) / \mathrm{mL}\right)$ after disinfection treatments at $7762 \mathrm{~min}$. Detection limit was $0.8 \log \mathrm{TCID}_{50} / \mathrm{mL}$. Results are the mean of 6 repetitions \pm 777 standard deviation. $\mathrm{NaClO}$, sodium hypochlorite; PA, peracetic acid; LA, lactic acid; AA, 778 acetic acid; CA, citric acid.

779

780

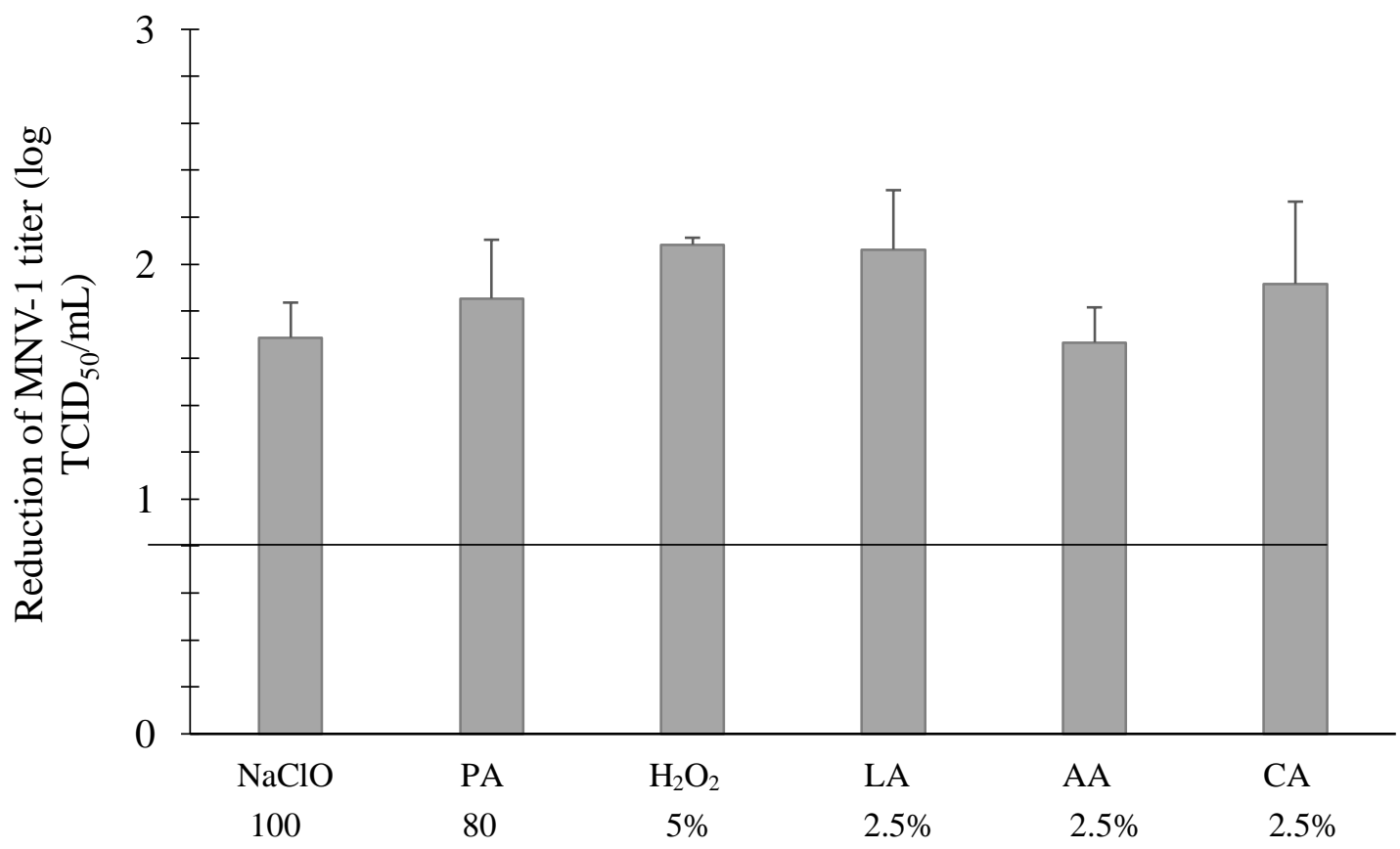

781

782

783 
Figure 3. Population (log Colony-forming unit (CFU)/g strawberry) of total aerobic

785

786

787

788

789

790 mesophylls (TAM) (grey), or molds and yeasts (M\&Y) (white) on strawberries. Values are the mean of 3 reps \pm standard deviation. Different letters indicate significant statistically differences $(P<0.05)$ among treatments. Remaining counts $(\log \mathrm{CFU} / \mathrm{mL})$ of TAM $(\bullet)$, or M\&Y $(\boldsymbol{\Delta})$ in washing solutions. Values were obtained from one sample. The straight line indicates the detection limit (dl). NaClO, sodium hypochlorite; PA, peracetic acid; LA, lactic acid; AA, acetic acid; CA, citric acid.

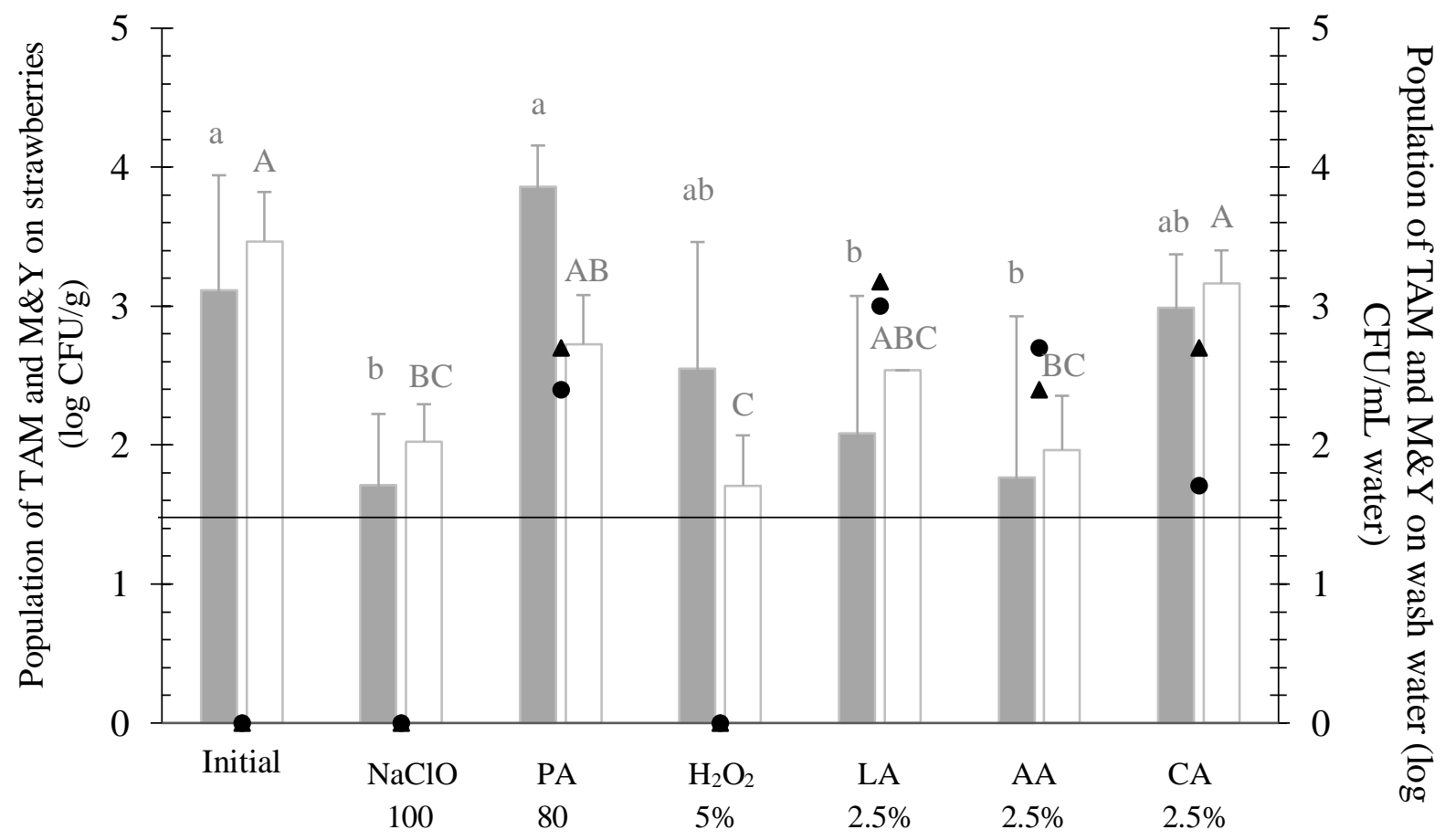

